\title{
Provisions of Indonesian Medical Discipline Sanctions to Protect The Rights of Patient be Reviewed From Theprinciple of The Establishment of Legislation
}

\author{
Ketentuan Sanksi Disiplin Kedokteran Indonesia Dalam Upaya Perlindungan Hak Pasien \\ Ditinjau Dari Asas Pembentukan Peraturan Perundang-Undangan
}

Wellem Hendra Balubun, Valentinus Suroto, Edi Sumarwanto

email: balubunivan@gmail.com

Health Law Master Program, Soegijapranata Catholic University of Semarang

\begin{abstract}
This study aims to determine, first: the effectiveness of the provisions of medical discipline sanctions for doctors and dentists to protect the rights of patients be reviewed from the principles of the establishment of legislation. Second: the mechanism of sanctioning Medical Discipline for doctors and dentists.
\end{abstract}

This research uses a normative juridical approach. The specification of this research is descriptive analytical. The type of data used is secondary data obtained through literature study and then analyzed qualitatively and drawn conclusions with deductive and inductive thought method.

The results of this study show that first: the provisions of Indonesian medical discipline sanction based on the principle of Clarity of Purpose, medical discipline sanction is established with a clear purpose that is as a form of guidance and supervision of medical practice in Indonesia. Based on the principle of Implementation, medical discipline sanction is said to be implemented because it has been regulated in the Regulation of KKI (Perkonsil) Number 50 of 2017 on the Procedures for Handling Cases of Alleged Violations of Doctor and Dentist Discipline. Based on the principles of Usability and Useful, by looking at the background of the formation of medical disciplinary sanctions which, among others, the high number of disciplinary violations, then disciplinary sanctions are really needed and yet not beneficial to the community. The principle of Clarity Formulation, the formulation of medical discipline sanction is clear and not multitasker so it can be easily understood. From the results of this analysis can be said that the provisions of disciplinary sanctions are effective. Secondly, the mechanism of sanction is set in number 50 of 2017 on the Procedures for Handling the Case of Alleged Discipline of Doctor and Dentist, which regulates the procedure and also the authority in the imposition of sanctions and the implementation of sanctions. The mechanism is the process of imposition of sanctions is the authority of MKDKI while the implementation of the decision of sanctions unification is the authority of KKI.

Keywords: disciplinary sanctions, patient rights, legislation 


\section{PENDAHULUAN}

Undang-undang Dasar 1945 mengamanatkan bahwa negara wajib melindungi segenap bangsa Indonesia dan seluruh tumpah darah Indonesia. Salah satu bentuk perlindungan yang dimaksud adalah perlindungan terhadap kesehatan setiap warga negara. Hal ini sebagaimana diatur di dalam Pasal $28 \mathrm{H}$ ayat (1) yang menyebutkan bahwa "Setiap orang berhak hidup sejahtera lahir dan batin, bertempat tinggal, dan mendapatkan lingkungan hidup yangbaik dan sehat serta berhak memperoleh pelayanan kesehatan."

Dalam rangka mewujudkan amanat tersebut, maka perlu dilakukan upaya peningkatan di bidang pelayanan kesehatan yang diselenggarakan oleh para tenaga kesehatan dan juga dokter dan dokter gigi (untuk selanjutnya dalam penulisan dipakai kata dokter).Praktik kedokteran merupakan pelayanan utama dari berbagai kegiatan dalam penyelenggaraan upaya kesehatan.

Praktik kedokteran adalah rangkaian kegiatan yang dilakukan oleh dokter terhadap pasien dalam melaksanakan upaya kesehatan. Baik di dunia barat, tempat asal kedokteran dikenal, maupun di lingkungan kebudayaan dan peradaban sekarang senantiasa diharapkan suatu hubungan antara dokter dan pasien secara pribadi dan tidak tergantung pada pihak yang ketiga. Akan tetapi, dengan semakin interdependennya segala segi kehidupan manusia, hubungan dokter pasien kini sangat memerlukan intervensi pihak lain, baik berupa sarana teknologi, kendali sosial, pengawasan pemegang kebijakan, pengaturan oleh norma, bahkan pembatasan oleh nilai, keyakinan dan sikap yang dianut masyarakat yang beradab. Namun demikian bagi dokter tentu sangat penting untuk pertama-tama menciptakan hubungan dengan pasien atas dasar kepercayaan. ${ }^{1}$ Praktik kedokteran yang dahulu seakanakan hidup terisolir, tak tersentuh, kini mulai dimasuki hukum. Di Indonesia mulai sekitar tahun 1980 tampak adanya interaksi antara hukum dengan pelayanan kesehatan (kedokteran).

Dalam menangani seorang pasien dokter tidak dapat menjanjikan sebuah kesembuhan, karena tubuh manusia bersifat kompleks dan tidak dapat dimengerti sepenuhnya. Belum diperhitungkan variasi yang tedapat pada setiap pasien: usia, psikis, tingkat penyakit, sifat penyakit, komplikasi, dan lain-lain. ${ }^{2}$ Selain faktor-faktor dari pasien seorang dokter juga tidak akan luput dari kesalahan dalam melaksanakan tugasnya sehari-hari.Akibatnya sering terjadi suatu peristiwa yang bersifat negatif (negatif outcome) sebagai bagian dari risiko yang harus ditanggung oleh pasien. Karena itu, dokter dalam bekerja selalu disangkutkan dengan masalah hukum sebagai pertanggungjawaban atas akibat tindakan medis yang bersifat negatif.

Seorang dokter sebagai pengemban profesi harus bertanggungjawab dalam menjalankan profesinya. Karena tanggungjawab dokter dalam hukum sedemikian luasnya, maka dokter juga harus mengerti dan memahami ketentuan-ketentuan hukum yang berlaku dalam pelaksanaan profesinya. Termasuk di dalamnya tentang pemahaman hak dan kewajiban dalam menjalankan profesi sebagai dokter. ${ }^{3}$

\footnotetext{
'Lumenta Benyamin, 1989. Dokter Citra, Peran, dan Fungsi, Yogyakarta : Kanisius, hal. 18

${ }^{2}$ Guwandi J, 2006. Dugaan Mallpraktek Medik \& Draf RPP : Perjanjian Teraupeutik antara Dokter dan Pasien, Jakarta : FKUI. hal 2

${ }^{3}$ Istafandyarie Anny, 2006. Tanggung Jawab Hukum dan Sanksi bagi Dokter. Buku I, Jakarta: Prestasi Pustaka. hal 3.
} 
Berkaitan dengan profesi kedokteran, belakangan marak diberitakan dalam mass media, baik melalui media elektronika maupun media cetak bahwa banyak ditemui malpraktik yang dilakukan kalangan dokter. Tuntutan hukum terhadap dokter yang diduga melakukan malpraktik diberbagai negara setiap tahun semakin meningkat.

Di Jepang, trend memperkarakan secara hukum dugaan "malpraktik" meningkat sangat tajam. Data dari Mahkama Agung Jepang menunjukkan peningkatan sebanyak 100\%, yaitu dari 487 kasus pada tahun 1995 menjadi 987 kasus pada tahun 2003. Di Singapura, walaupun tidak ada data formal tentang dugaan "malpraktik", dalam Singapore Medical Association Workgroup's Report on Avoiding Medical Accident and Improving Patient Information (Marc 2003), dilaporkan selama periode 1999 sampai 2001, dari 5,608 dokter di singapura 601 diantaranya dikomplain oleh masyarakat. Yang cukup mengagetkan adalah hampir separuh $(43,7 \%)$ dokter-dokter yang dikomplain ternyata memang tebukti melanggar standart of care. Di hongkong, berdasarkan data dari Medical Protection Society (sejenis asuransi ganti rugi untuk kasus yang dikomplain karena malpraktik), menunjukkan kondisi yang cukup mengagetkan. Terjadi peningkatan hampir 200\% jumlah ganti rugi yang harus dibayar asuransi. Dari rata-rata sekitar HK $\$ 4,000$ pada tahun 1994, menjadi rata-rata sekitar HK \$12,000 pada tahun 2003.Di Indonesia, menurut laporan Lembaga Bantuan Hukum Kesehatan Pusat tercatat kurang lebih terdapat 150 kasus malpraktik, walau sebagian besar tidak sampai ke meja hijau. Demikian pula laporan masyarakat kepada Ikatan Dokter Indonesia (IDI) dari tahun 1998 sampai 2006 tercatat 306 kasus pengaduan dugaan malpraktik. ${ }^{4}$

Menurut SG Wibisono, dalam tahun 2006 hingga 2012 tercatat ada 182 kasus malpraktik atau kelalaian medis yang terbukti dilakukan oleh dokter di seluruh Indonesia. ${ }^{5}$

Dalam upaya memberikan perlindungan dan menjamin hak penerima pelayanan kesehatan, pada tahun 2004 Pemerintah membentuk Undang-Undang Praktik Kedokteran.Pasal 54 ayat (1) Undang-Undang Praktik Kedokteran menyebutkan bahwa:

"Dalam rangka terselenggaranya praktik kedokteran yang bermutu dan melindungi masyarakat sesuai dengan ketentuan sebagaimana dimaksud dalam Undang-undang ini, perlu dilakukan pembinaan terhadap dokter atau dokter gigi yang melakukan praktik kedokteran."

Pembinaan sebagaimana dimaksud dilakukan oleh Majelis Kehormatan Disiplin Kedokteran Indonesia.

Dalam Pasal 64huruf a Undang-Undang Nomor 29 Tahun 2004 tentang Praktik Kedokteran disebutkan bahwa tugas Majelis Kehormatan Disiplin Kedokteran Indonesia ialah "menerima pengaduan, memeriksa, dan memutuskan kasus pelanggaran disiplin dokter dan dokter gigi yang diajukan". Selanjutnya menurut Pasal 69, Majelis Kehormatan Disiplin Kedokteran Indonesia juga berwenang memberikan sanksi kepada dokter yang melakukan pelanggaran disiplin. Sanksi yang diberikan yakni:

\footnotetext{
${ }^{4}$ Syahrul Machmud, 2008. Penegakan Hukum dan Perlindungan Hukum bagi Dokter yang Diduga Melakukan Medikal Malpraktek, Jakarta : Mandar Maju. hal. 1-3

${ }^{5}$ SG Wibisono, "Sampai Akhir 2012, Terjadi 182 Malpraktek", Tempo.co Nasional, 25 Maret 2013, internet, 16 juni 2015, http://nasional.tempo.co/read/news/2013
} 
1. Pemberian peringatan tertulis;

2. Rekomendasi pencabutan surat tanda registrasi atau surat izin praktik; dan/atau

3. Kewajiban mengikuti pendidikan atau pelatihan di institusi pendidikan kedokteran atau kedokteran gigi.

Terkait dengan sanksi pencabutan surat tanda registrasi atau surat izin praktik; dan/atau kewajiban mengkuti pendidikan atau pelatihan di institusi pendidikan kedokteran atau kedokteran gigi, maka Majelis Kehormatan Disiplin Kedokteran Indonesia merekomendasikan kepada Konsil Kedokteran Indonesia untuk selanjutnya akan diteruskan kepada pihak terkait.

Menurut Dr. Sabir Alwy (Wakil ketua MKDKI), kurangnya komunikasi yang baik antara dokter dengan pasien menjadi penyebab banyaknya pengaduan dugaan pelanggaran disiplin (masyarakat menyebutnya malpraktik) oleh dokter dan dokter gigi ${ }^{6}$. Berdasarkan data dari Majelis Kehormatan Disiplin Kedoteran Indonesia jumlah pengaduan dari tahun 2006 sampai awal juni 2016 terdapat 362 pengaduan. ${ }^{7}$ Profesional medis yang diadukan berdasarkan spesialisasi antara lain internist, mata, anastesi, syaraf, kulit, paru, jantung, ortopedi, kesehatan jiwa, forensik, bedah mulut, dan masih banyak lagi. ${ }^{8}$ Namun demikian berita tentang pelanggaran disiplin kedokteran masih sering menghiasi media masa, baik media cetak maupun media elektornik.

Dalam pembentukan peraturan perundang-undangan, sebuah undang-undang diharuskan dibentuk berdasarkan asas pembentukan peraturan perundang-undangan yang baik. Dalam Pasal 5 Undang-Undang Nomor 12 Tahun 2011 tentang Pembentuakn Peraturan Perundangundangan disebutkan asas pembentukan peraturan perundang-undangan yang baik meliputi:

1. Kejelasan tujuan;

2. Kelembagaan atau pejabat pembentuk yang tepat;

3. Kesesuaian antara jenis, hierarki, dan materi muatan;

4. Dapat dilaksanakan;

5. Kedayagunaan dan kehasilgunaan;

6. Kejelasan rumusan; dan

7. Keterbukaan.

\footnotetext{
${ }^{6}$ Internet, Dugaan Pelanggaran Disiplin Terbanyak Akibatnya Kurangnya Komunikasi Dokter dan Pasien, 5 Juni 2016, http://www.depkes.go.id/article/print/1519/dugaan-pelanggaran-disiplinterbanyak-akibat-kurangnya-komunikasi-dokter-dan-pasien.html

${ }^{7}$ Laporan Sekretariat MKDKI 2011-2016. Tidak dipublikasikan

${ }^{8}$ Pulo Lasman Simanjuntak, "Masyarakat Dipersilahkan Mengadu ke MKDKI Bila Ada Dokter Langgar Etika, Dsiplin, dan Pidana", Internet, 5 Juni 2016, http://www.beritarayaonline.com/2015/05/masyarakat-dipersilahkan-mengadu-

ke.html\#.V1q2ITV97IU
} 
Menurut teori Filsafati yang dikemukakan oleh Jeremy Bentham di dalam bukunya yang berjudul "Legal Theory", suatu produk peraturan (produk hukum) dikatakan baik apabila mempunyai sifat berlaku secara filosofis, sosiologis, dan yuridis. ${ }^{9}$

Salah satu tujuan Undang-Undang Praktik Kedokteran yang di dalamnya diatur tentang ketentuan sanksi disiplin dokter adalah untuk melindungi hak penerima pelayanan kesehatan, maka dengan dibuatnya Undang-Undang Praktik Kedokteran hak penerima pelayanan kesehatan untuk memperoleh pelayanan kesehatan yang berkualitas seharusnya dapat terwujud. Namun kenyataan menunjukkan bahwa hampir secara berkala dapat dibaca dalam media cetak maupun dilihat di media elektronik adanya berbagai berita tentang malpraktik medis. Pertanyaan yang muncul adalah apakah ketentuan sanksi Disiplin Kedokteran sudah cukup efektifdalam melindungi hak pasien? Menurut Soerjono Soekanto, salah satu faktor yang mempengaruhi penegakan hukum adalah hukumnya sendiri. Teori pembentukan perundang-undangan mengatakan bahwa dalam pembentukan suatu perundang-undangan (produk hukum) harus berpedoman pada asas pembentukan perundang-undangan. Pertanyaan selanjutnya adalah apakah ketentuan sanksi disiplin dibentuk sesuai dengan asas pembentukan perundang-undangan?.

Berdasarkan uraian tersebut, perlu dilakukan penelitian mengenai "Ketentuan Sanksi Disiplin Kedokteran Dalam Upaya Perlindungan Hak Pasien Ditinjau Dari Asas Pembentukan Peraturan Perundang-undangan".

\section{RUMUSAN MASALAH}

Berdasarkan latar belakang diatas, maka dirumuskan permasalahan sebagai berikut.

1. Bagaimana efektivitas ketentuan sanksi disiplin kedokteran bagi dokter dan dokter gigi dalam upaya perlindungan hak pasien ditinjau dari asas pembentukan peraturan perundang-undangan?

2. Bagaimana mekanisme pemberian sanksi disiplin kedokteran bagi dokter?

\section{METODE PENELITIAN}

\section{Metode Pendekatan}

Metode yang digunakan dalam penelitian adalah yuridis normatif, yaitu suatu cara meneliti dalam penelitian hukum untuk mengkaji hukum normatif. Metode pendekatan yuridis normatif pada penelitian ini akan mengacu pada Pasal 69 Undang-Undang Nomor 29 Tahun 2004 tentang Praktik Kedokteran dan Pasal 5 Undang-Undang Nomor 12 Tahun 2011 tentang Pembentukan PeraturanPerundang-undangan.

\section{Spesifikasi Penelitian}

Spesifikasi yang digunakan dalam penelitian ini adalah deskriptif analitis, yaitu membuat deskripsi atau gambaran secara sistematis, faktual dan akurat mengenai fakta, sifat dan hubungan antara fenomena atau gejala yang diteliti sambil menganalisisnya dengan mencari sebab akibat dari suatu hal kemudian menguraikannya secara konsisten dan sistematis serta logis. Dalam penelitian ini, peneliti akan membuat gambaran tentang efektivitas ketentuan sanksi disiplin kedokteran Indonesia dalam upaya perlindungan

\footnotetext{
${ }^{9}$ www.academia.edu.

KonsekuensiYuridisSuatuProdukHukumyangTidakMemilikiSifatBerlakuSecaraSosiologis, internet, 22 maret 2016, https://www.academia.edu/12011021/
} 
hak pasien ditinjau dari asas pembentukan perundang-undangan. Kemudian akan dianalisis dengan menggunakan teori hukum, asas hukum dan peraturan perundangundangan terkait.

\section{Variabel dan Defenisi Operasional}

Variabel adalah ukuran atau ciri yang dimiliki oleh anggota-anggota suatu kelompok yang berbeda dengan yang dimiliki oleh kelompok lain. ${ }^{10}$ Variabel dalam penelitian ini dibedakan menjadi:

1) Variabel Bebas

Dalam penelitian ini yang menjadi variabel bebas adalah ketentuan sanksi disiplin kedokteran Indonesia.

2) Variabel Terikat

Dalam penelitian ini yang menjadi veriabel terikat adalah perlindungan hak pasien.

3) Veriabel Perantara

Dalam penelitian ini yang menjadi variabel perantara adalah asas pembentukan peraturan perundang-undangan.

Defenisi operasional dalam penelitian ini meliputi sebagai berikut.

a. Efektivitas diartikan sebagai ketepatan penggunaan, hasil guna atau menunjang tujuan. Efektivitas merupakan unsur pokok untuk mencapai tujuan atau sasaran yang telah ditentukan di dalam setiap organisasi, kegiatan ataupun program. Disebut efektif apabila tercapai tujuan ataupun sasaran seperti yang telah ditentukan. Sedangkan, ketentuan sanksi dikatakan efektif jika ketentuan sanksi mencerminkan asas pembentukan peraturan perundang-undangan.

b. Sanksi adalah suatu tindakan reaktif dan antisipatif terhadap pelaku perbuatan salah. Sanksi disiplin kedokteran adalah sanksi yang dijatuhkan oleh Majelis Kehormatan Disiplin Kedokteran Indonesia.

c. Asas-asas pembentukan perundang-undangan yang adalah asas hukum yang memberikan pedoman dan dasar dalam membentuk sebuah peraturan perundang-undangan.Dalam penelitian ini akan digunakan empat asas, yakni

a) Kejelasan tujuan;

b) Dapat dilaksanakan;

C) Kedayagunaan dan kehasilgunaan;

d) Kejelasan rumusan; dan

d. Perlindungan hukum adalah suatu jaminan yang diberikan oleh pihak yang berwenang kepada semua pihak, untuk melaksanakan hak dan kewajiban hukum yang dimilikinya, dalam kapasitasnya sebagai subyek hukum. Dalam arti sempit hak adalah kewajiban orang lain, hak adalah kaitan dengan dari kewajiban (the correlative of a duty). Hak pasien tertuang dalam Pasal 4 sampai Pasal 8 UndangUndang Nomor 36 Tahun 2009 Tentang Kesehatan. Sesuai dengan teori perlindungan hukum, maka dikatakan hak terlindungi jika pasien dapat melaksanakan haknya untuk mendapat pelayanan kesehatan yang optimal.

\footnotetext{
${ }^{10}$ Soekidjo Notoatmodjo, 2010, Metodologi Penelitian Kesehatan, Jakarta : Rineka Cipta. hal. 103
} 


\section{Objek Penelitian}

Objek pada penelitian ini adalah asas pembentukan peraturan perundang-undangan yang tercantum dalam pasal 5 UU No. 12 Tahun 2011 tentang Peraturan Pembentukan Perundang-undangan yang antara lain:

1) Kejelasan Tujuan;

2) Dapat dilaksanakan;

3) Kedayagunaan dan kehasilgunaan;

4) Kejelasan rumusan.

\section{Jenis data dan sumber data}

Data yang peneliti gunakan adalah data sekunder. Data sekunder adalah data yang diperoleh bukan dari tangan pertama, tetapi sudah diolah dan sudah dipublikaskan. Menurut Soerjono Soekanto data sekunder, antara lain mencakup dokumen-dokumen resmi, buku-buku, hasil-hasil penelitian yang berwujud laporan, buku harian, dan seterusnya. Data sekunder dalam penelitian hukum meliputi bahan hukum primer, bahan hukum skunder dan bahan hukum tersier. ${ }^{11}$

1) Bahan Hukum Primer, adalah bahan-bahan hukum yang mempunyai kekuatan mengikat. ${ }^{12}$ Terdiri dari:

a) Undang-Undang Nomor 36 Tahun 2009 Tentang Kesehatan.

b) Undang-Undang Nomor 12 Tahun 2011 Tentang Peraturan Pembentukan Perundang-undangan.

c) Undang-Undang Nomor 29 Tahun 2004 Tentang Praktik Kedokteran.

d) Permenkes Nomor 2052 Tahun 2011 Tentang Izin Praktik Dan Pelaksanaan Paktik Kedokteran.

e) Peraturan Konsil Kedokteran Indonesia Nomor 4 Tahun 2011 Tentang Disiplin Profesional Dokter dan Dokter Gigi.

f) Peraturan Konsil Kedokteran Indonesia Nomor 32 Tahun 2015 Tentang Tata Cara Penanganan Kasus Dugaan Pelanggaran Disiplin Dokter dan Dokter Gigi.

2) Bahan Hukum Sekunder, adalah bahan-bahan yang erat hubungannya dengan bahan hukum primer dan dapat membantu menganalisis dan memahami bahan hukum premier. ${ }^{13}$ Terdiri dari:

a) Karya ilmiah, buku, hasil penelitian di bidang kedoteran, bidang hukum dan peraturan pembentukan perundang-undangan.

b) Artikel, jurnal, atau majalah di bidang kedokteran, bidang hukum dan peraturan pembentukan perundang-undangan.

3) Bahan Hukum Tersier, adalah bahan-bahan hukum yang memberikan informasi tentang bahan hukum premier dan bahan hukum sekunder. ${ }^{14}$ Terdiri dari:

a) Kamus Hukum;

b) Kamus Besar Bahasa Indonesia;

\footnotetext{
${ }^{11}$ Soerjono Soekanto, 2014, Pengantar Penelitan Hukum Cetakan III, Jakarta: Universitas Indonesia. hal 12.

${ }^{12}$ Ronny Hanitijo Soemitro, op. cit., hal 11.

${ }^{13}$ Ibid

${ }^{14}$ Ibid., hal 12.
} 
c) Kamus Bahasa Inggris-Indonesia; dan

d) Bahan rujukan Lainnya yang sejenis.

\section{Metode Pengumpulan Data}

Metode pengumpulan data adalah tata cara atau langkah-langkah peneliti untuk mendapatkan data penelitian, peneliti harus menggunakan teknik dan prosedur pengumpulan data yang sesuai dengan jenis data yang dibutuhkan, apakah data berbentuk kualitatif atau kuantitatif. ${ }^{15}$ Teknik pengumpulan data dalam penelitian ini, yaitu studi pustaka. Studi pustaka merupakan metode pengumpulan data yang dilakukan melalui data tertulis. ${ }^{16}$

\section{Metode Analisis Data}

Informasi atau data yang dikumpulkan melaui studi pustaka akan dinalisis secara kualitatif. Penarikan kesimpulan dengan menggunakan metode berpikir deduktif dan induktif. Deduktif yaitu cara berpikir dalam penarikan kesimpulan yang ditarik dari sesuatu yang sifatnya umum yang sudah dibuktikan bahwa dia benar dan kesimpulan itu ditujukkan untuk sesuatu yang sifatnya khusus. Sedangkan induktif yaitu, cara berpikir dalam penarikan kesimpulan yang ditarik dari sesuatu yang sifatnya khusus untuk disimpulkan pada sesuatu yang sifatnya umum. ${ }^{17}$

\section{PEMBAHASAN}

\section{Efektivitas Ketentuan Sanksi Disiplin Kedokteran dalam Upaya Perlindungan Hak Pasien Ditinjau dari Asas Pembentukan Peraturan Perundang-undangan}

Dalam Bab II telah disebutkan bahwa pembentukan produk hukum (undang-undang) dipengaruhi oleh politik, sehingga apabila dalam pembentukannya tidak dikontrol, maka dapat merugikan warga negara. ${ }^{18}$ Bertolak dari pendapat ini, ketentuan sanksi disiplin kedokteran dalam Undang-Undang Nomor 29 Tahun2004 sebagai produk hukum apabila tidak dikontrol, maka dapat merugikan pasien. Salah satu alat kontrolnnya adalah asas-asas pembentukan peraturan perundang-undangan yang baik sebagaimana diatur dalam Undang-Undang Nomor 12 Tahun 2011.

Pada sub pokok bahasan ini akan dilakukan analisis terhadap ketentuan sanksi disiplin kedokteran Indonesia ditinjau dari asas-asas pembentukan perundang-undangan yang baik. Analisis dilakukan untuk mengetahui apakah ketentuan sanksi disiplin kedokteran Indonesia telah sesuai denganasas-asas pembentukan perundang-undangan yang baik. Setelah dianalisis, maka akan ditarik sebuah kesimpulan, seberapaefektifkah ketentuan sanksi disiplin kedokteran Indonesia dalam upaya perlindungan hak pasien. Asas-asas pembentukan perundang-undangan yang digunakan untuk menganalisis efektivitas sanksi disiplin kedokteran Indonesia meluputi asaskejelasan tujuan, dapat dilaksanakan, kedayagunaan dan kehasilgunaan, dan kejelasan rumusan.

\footnotetext{
${ }^{15}$ Iskandar, 2008, Metodologi Penelitian Pendidikan dan Sosial (Kualitatif dan Kuantitatif), Jakarta: GP Press. hal 178.

${ }^{16}$ Soerjono Soekanto, Op.Cit., hal 12.

${ }^{17}$ Sedarmayanti \& Syarifudin Hidayat,2002, Metodologi Penelitian, Bandung : Mandar Maju. hal 23

${ }^{18}$ Lihat: Bab II., hal. 37.
} 


\section{Efektivitas Ketentuan Sanksi Disiplin Kedokteran Berdasarkan Asas Kejelasan Tujuan}

Menurut penjelasan Undang-Undang Nomor 12 Tahun 2011 tentang Peraturan Pembentukan Perundang-undangan, yang dimaksud dengan "asas kejelasan tujuan" adalah bahwa setiap pembentukan peraturan perundang-undangan harusmempunyai tujuan yang jelas yang hendak dicapai.

Tujuan yang jelas dari pembentukan peraturan perundang-undangan dicantumkan dalam bagian konsideran (menimbang), termasuk pula pada bagian penjelasan. Tujuan ini memberikan petunjuk bagi setiap orang yang tersangkut dalam pelaksanaan suatu undang-undang, agar dapat mengetahui secar lebih mudah tentang maksud pembuat undang-undang.

Tujuan dari ketentuan sanksi disiplin kedokteran secara eksplisit disebutkan dalam bagian menimbang huruf d Undang-Undang Praktik Kedokteran, yaitu untuk memberikan perlindungan dan kepastian hukum kepada penerima pelayanan kesehatan, dokter, dan dokter gigi. Selain itu, dijelaskan dalam bagian penjelasan atas UndangUndang Praktik Kedokteran bahwa tujuan dari ketentuan sanksi disiplin kedokteran adalah sebagai bentuk pembinaan dan pengawasan terhadap praktik kedokteran.

Dalam menilai bahwa sanksi disiplin kedokteran telah sesuai dengan asas kejelasan tujuan, maka acuan yang dipakai adalah apakah sanksi disiplin kedokteran telah mencapai tujuan yakni sebagai pembinaan dan pengawasan terhadap praktik kedokteran.

Dalam Kamus Besar Bahasa Indonesia (KBBI), pembinaan merupakan sebuah proses atau tindakan untuk menjadi lebih baik. Sedangkan pengawasan adalah penilikan dan penjagaan. Suatu obyek diawasi agar mencapai sasaran atau tujuan sebagaimana yang telah ditetapkan. Menurut pengertian ini, maka sanksi disiplin kedokteran dikatakan efektif untuk melindungi hak pasien jika terjadi peningkatan pada profesi dokter ke arah yang lebih baik dari keadaan semula, dan juga memastikan dokter dapat menjalankan fungsi sebagai pemberi pelayanan kesehatan dengan baik.

Data dari IDI menyebutkan bahwa dari tahun 1998 sampai 2006 (sebelum lahirnya UU Praktik Kedokteran) tercatat 306 kasus pengaduandugaan malpraktik, ${ }^{19}$ kemudian MKDKI menyebutkan dari tahun 2006 sampai awal juni 2016 (setelah lahirnya UU Praktik Kedokteran) terdapat 362 pengaduan. ${ }^{20}$ Dari data ini dapat dilihat bahwa tidak terjadi perubahansesuai asa pembentukan sanksi ini, sebab bukannya terjadi penurunan jumlah pengaduan, tetapi cenderung meningkat. Hal ini membuktikan bahwa sanksi disiplin kedokteran tidak membawa perubahan ke arah yang lebih baik dari sebelumnya, yang artinya sanksi disiplin belum efektif sebagai bentuk pembinaan terhadap dokter.

Terkait dengan fungsi sanksi disiplin sebagai bentuk pengawasan, maka dapat dikatakan belum efektif. Sebab dilihat dari data jumlahpengaduan kepada MKDKI, antara tahun 2006 sampai 2010 terdapat 125 pengaduan, meningkat menjadi 237 pengaduan di antara tahun 2011 sampai 2016. Data ini mengindikasikan masih banyak kasus pelanggaran disiplin yangterjadi, yang diartikan sebagaiketidakberhasilan sanksi disiplin untuk mengawasi kinerja dokter. Seperti kasus yang terjadi di Cowa Sulawesi selatan,Manajemen Rumah Sakit Umum Daerah Syekh Yusuf Kabupaten Gowa

${ }^{19}$ Lihat: Bab I., hal. 4.

${ }^{20}$ Lihat: Bab I., hal. 6. 
menindak tegas dokter Febriani seorang dokter jaga di Instalasi Gawat Darurat yang menolak pasien demam berdarah dengue. Manajemen rumahsakit meminta tim pengawas internal dan tim etik dokter untuk mengevaluasi dokter yang menolak merawat Syamsuddin Daeng Ngawing (65) hingga akhirnya pasien meninggal dunia karena terlambat mendapatkan perawatan. ${ }^{21}$ Dari kasus ini jelas bahwa dokter tersebut telah mengabaikan hak pasien untuk mendapatkan pelayanan kesehatan dan juga melakukan pelanggran disiplin yaitu "Menolak atau menghentikan tindakan/asuhan medis atau tindakan pengobatan terhadap pasein tanpa alasan yang layak dan sesuai dengan ketentuan etika profesi atau peraturan perundang-undangan yang berlaku", yang diatur dalam Pasal 3 ayat (2) huruf pPerkonsil Kedokteran Indonesia Nomor 4 Tahun 2011 tentang Disiplin Profesional Dokter dan Dokter Gigi Untuk memberikan efek jera,maka seharusnya dokter tersebut diberikan sanksi disiplin agar upaya perlindungan hak pasien dapat terlaksana. Sanksi disiplin yang diberikan sesuai Pasal 69 ayat (3) Undang-Undang Praktik Kedokteran yang kemudian dituangkan dalam aturan pelaksanaannya yakni Perkonsil Nomor 50 Tahun 2017 tentang Tata Cara Penanganan Pengaduan Disiplin Dokter dan Dokter Gigi, yaitu berupa:

a. Peringatan tertulis, dokter yang dikenakan sanksi peringatan tertulis tetap dapat melakukan praktik kedokteran dengan pengawasan;

b. Rekomendasi pencabutan STR atau SIP, jika STR dicabut, maka secara otomatis SIP pun tidak berlaku yang artinya dokter tidak dapat melakukan praktik kedokteran. Sanksi pencabutan STR dapat bersifat sementara paling lama 2 tahun atau dapat dicabut selamanya; dan/atau

c. Kewajiban mengikuti pendidikan atau pelatihan di institusi pendidikan kedokteran atau kedokteran gigi, dokter yang dikenakan sanksi iniwajib mengikuti pendidikan atau pelatihan di intitusi pendidikan kedokteran atau kedokteran gigi yang mana jenis, bentuk, dan waktu pelaksanaan ditentukan oleh MKDKI.

Upaya perlindungan hak pasien dalam kasus di atas ialah upaya perlindungan terhadap hakpasien yang diatur dalam Pasal 5 ayat (2) Undang-Undang Nomor 36 Tahun 2009 tentang kesehatan yaitu "setiap orang mempunyai hak yang sama dalam memperoleh pelayanan kesehatan yang aman, bermutu, dan terjangkau”. Dengan begitu, tujuan pengaturansanksi disiplin kedokteran dapat terlaksana, dan pada akhirnya pembangunan di bidang kesehatan dapat terlaksana dengan optimal.

Berdasarkan analisis diatas, dapat dikatakan bahwa ketentuan sanksi disiplin kedokteran Indonesia telah memenuhi "Asas Kejelasan Tujuan", sebab mempunyai tujuan yang jelas yaitu sebagai bentuk pembinaan dan pengawasan terhadap praktik kedokteran, namun dalam pelaksanaannya sanksi disiplin kedokteran tidak efektif dalam melindungi hak pasien.

2. Efektivitas Ketentuan Sanksi Disiplin Kedokteran Berdasarkan Asas Dapat Dilaksanakan

Asas "dapat dilaksanakan" berkaitan dengan penegakan peraturan perundangundangan. Tidak ada gunanya suatu peraturan perundang-undangan yang tidak dapat ditegakkan. Dengan mengacu pendapat tersebut, maka dapat dikatakan bahwa asas ini menyangkut jaminan dapat dilaksanakannya apa yang dimuat dalam suatu peraturan.

\footnotetext{
${ }^{21}$ https://nasional.tempo.co/read/745941/abaikan-pasien-dokter-rsud-syekh-yusuf-diberhentikan
} 
Suatu aturan harus didukung oleh kondisi sosial yang cukup, sarana yang memadai bagi instansi atau dinas yang akan melaksanakan suatu peraturan, dukungan keuangan yang cukup, dan sanksi yang sesuai.

Sejalan dengan teori diatas, penjelasan Pasal 5 Undang-Undang Nomor 12 Tahun 2011 tentang Pembentukan Peraturan Perundang-undangan, menyebutkan bahwa yang dimaksud dengan "asas dapat dilaksanakan" adalahbahwa setiap pembentukan peraturan perundang-undanganharus memperhitungkan efektivitas peraturan perundang-undangantersebut di dalam masyarakat, baik secara filosofis,sosiologis, maupun yuridis.

Sanksi disiplin kedokteran merupakan bagian undang-undang Praktik Kedokteran yang yang harus ditegakkan.Jika berbicara mengenai penegakkan sanksi, sesungguhnya berbicara mengenai apakah sanksi tersebut dapat dilaksanakan atau tidak. Parameter untuk menentukan bahwa sanksi disiplin kedokteran Indonesia efektif atau tidak berdasarkan asas dapat dilaksanakan ialah sanksi disiplin kedokteran Indonesia dapat dilaksanakan atau tidak.

Dapat dilaksanakannya sanksi disiplin kedokteran dapat dianalisis dengan melihat tata cara pelaksanaan putusan MKDKI. Putusan MKDKI bersifat final dan berkekuatan tetap serta mengikat Teradu dan KKI sesuai Pasal 82 ayat (1) Perkonsil Nomor 50 Tahun 2017. Pelaksanaannya diatur dalam Pasal 84 ayat (1) yangmenyebutkan bahwa:“Ketua MKDKI menerbitkan Keputusan MKDKI atas setiap Putusan yang telah dibacakan di sidang terbuka untuk umum kepada ketua KKI", ayat (2) menyebutkan bahwa: "Ketua MKDKI menyerahkan Keputusan MKDKI kepada Ketua KKI dilakukan paling lama 7 (tujuh) hari setelah sidang pembacaan putusan.Pasal 85 ayat (1) menjelaskan bahwa untuk melaksanakan keputusan MKDKI menetapkan teradu tidak bersalah atau tidak ditemukan Pelanggaran Disiplin, KKI menerbitkan Surat Keputusan dan menyerahkan salinan Keputusan MKDKI kepada teradu, kemudian pada ayat (2) pasal ini diatur mengenai waktu penyerahan Keputusan KKI dan Salinan Keputusan MKDKI yaitu 7 (tujuh) hari setelah KKI menerima salinan Keputusan MKDKI. Untuk Keputusan MKDKI yang menyatakan teradu bersalah, dalam Pasal 86 ayat menjelaskan bahwa, KKI menerbitkan Surat Keputusan untuk melaksanakan keputusan MKDKI paling lama 7 (tujuh) hari setelah menerima salinan putusan, kemudian Surat Keputusan KKI beserta Salinan Keputusan MKDKI disampaikan melalui surat tercatat paling lambat 7 (tujuh) hari sejak diterbitkan Surat Keputusan KKI kepada teradu, Fasyakes, dan seluruh pihak-pihak terkait yaitu Dinas Kesehatan Provinsi, Dinas Kesehatan Kabupaten/Kota yang menerbitkan SIP teradu, institusi pendidikan kedokteran atau kedokteran gigi tempat pelaksanaan sanksi reschooling.

Ketentuan di atas mengatur bahwa pelaksanaan Keputusan MKDKI sepenuhnya dilaksanakan oleh KKI dan wajib untuk dilaksanakan sesuai dengan Keputusan MKDKI, jika tidak sesuai maka KKI melanggar ketentuan dalam Perkonsil tersebut. Terkait rentang waktu pelaksanaan Keputusan MKDKI setelah diputuskan hingga dilaksanakan oleh KKI, sudah diatur secara tegas dalam Perkonsil ini, yaitu 7 (hari) untuk setiap proses untuk pelaksanaan Putusan baik di MKDKI maupun KKI.

Pelaksanaan sanksi disiplin kedokteran Indonesia sangat berpengaruh terhadap tercapainya tujuan pembentukan sanksi tersebut yakni sebagai pembinaan dan pengawasan terhadap praktik kedokteran. Terkait dengan pembinaan dan pengawasan 
terhadap praktik kedokteran, pada sub pokok bahasan sebelumnya (Efektivitas Ketentuan Sanksi Disiplin Kedokteran berdasarkan Asas Kejelasan Tujuan)telah dianalisis yang menghasilkan kesimpulan bahwa ketentuan sanksi disiplin belum efektif sebagai pembinaan dan pengawasan terhadap praktik kedokteran.

Menurut Sabir Alwy (Wakil ketua MKDKI), banyaknya pelanggaran disiplin yang terjadi akibat kurangnya komunikasi yang baik antara dokter dengan pasien. ${ }^{22}$ Komunikasi antara dokter dan pasien sangat dibutuhkan, kurangnya komunikasi antara dokter dan pasien dapat berakibat hak pasien untuk mengetahui informasi tentang tindakan medis dan perjalanan penyakitnya seperti yang diatur dalam Pasal 52 huruf a Undang-Undang Praktik Kedokteran tidak terpenuhi. Jika hal ini terjadi, maka dokter telah melakukan pelanggaran disiplin, yaitu "Tidak memberikan penjelasan yang jujur, etis, dan memadai (adequate information) kepada pasien atau keluarganya dalam melakukan Praktik Kedokteran yang diatur di dalam Pasal 3 ayat (2) huruf h Peraturan Konsil Kedokteran Indonesia Nomor 4 Tahun 2011 tentang Disiplin Profesional Dokter dan Dokter Gigi.

Seperti kasus yang terjadi pada tahun 2012 lalu, dokter Eko Medio Septiawan, Sp.OT diadukan ke MKDKI-P Jawa Tengah karena teradudianggap lalai dan menelantarkan pasien dengan tidak memberikan informasi yang akurat sebelum dan sesudah tindakan medis sehingga menyebabkan proses penyembuhan pasien yang berkepanjangan. Setelah dilakukan pemeriksaan oleh MKDKI-P Jawa Tengah, teradu terbukti melakukan pelanggaran disiplin dandijatuhkan sanksi. ${ }^{23}$

MKDKI-P Jawa Tengah memberikan sanksi berupa rekomendasi pencabutan STR selama 3 bulan kepada dokter Eko Medio Septiawan, Sp.OT karena terbukti melakukan pelanggaran disiplin yang dimaksudkan sebagai upaya perlindungan terhadap hak pasien khususnya "hak untuk mendapatkan penjelasan secara lengkap tentang tindakan medis". Upaya ini akan sia-sia jika keputusan ini tidak dilaksanakan oleh KKI, sebab meski diatur mengenai pelaksanaan dan juga waktu maksimal pelaksanaan namun tidak diatur terkait apa yang mesti dilakukan jika keputusan MKDKI tidak dilaksanakan atau pelaksanaannya melebihi waktu yang telah ditentukan.

Berdasar pada analisis di atas, maka dapat dikatakan bahwa sanksi disiplin kedokteran telah efektif untuk melindungi hak pasien berdasarkan "asas dapat dilaksanakan".

\section{Efektivitas Ketentuan Sanksi Disiplin Kedokteran Berdasarkan Asas Kedayagunaan dan Kehasilgunaan}

Pengertian "asas kedayagunaan dan kehasilgunaan" menurut penjelasan Pasal 5 Undang-Undang Nomor 12 Tahun 2011 ialah bahwa "setiap peraturan perundangundangan dibuat karena memang benar-benar dibutuhkan dan bermanfaat dalam mengatur kehidupan masyarakat, berbangsa, dan bernegara".

Bertolak dari pengertian di atas, maka parameter yang dipakai untuk menganalisis efektivitas sanksi disiplin kedokteran berdasarkan asas kedayagunaan dan kehasilgunaan adalah benar-benar dibutuhkan dan bermanfaat. Sanksi disiplin kedokteran dikatakan efektif apabila memang benar-benar dan bermanfaat bagi masyarakat.

\footnotetext{
${ }^{22}$ Lihat: Bab I., hal. 5.

${ }^{23}$ https://putusan.mahkamahagung.go.id/putusan/downloadpdf/b835f9cb949c2fb0a163a72fc54cc9db/ pdf.
} 
Dalam kenyataannya sanksi disiplin kedokteransangat dibutuhkan dalam masyarakat.Laporan masyarakat kepada Ikatan Dokter Indonesia (IDI) dari tahun 1998 sampai 2006 (sebelum lahirnya UU Praktik Kedokteran) tercatat 306 kasus pengaduan dugaan malpraktik. ${ }^{24}$ Seiring dengan banyaknya pengaduan dugaan malpraktik, kepercayaan masyarakat terhadap dokter pun semakin berkurang. Hal ini dibuktikan dengan banyaknya pasien dari Indonesia yang berobat keluar negeri, setiap tahunnya ada sekitar 600 ribu orang Indonesia yang berobat keluar negeri. Dikutip dari Vivanews.com, Direktur Jenderal Bina Upaya Kesehatan, Kementerian Kesehatan, Supriyantoro (sekarang sudah diganti) mengatakan bahwa menurut data World Bank tahun 2004 sekitar Rp70 triliundevisa negara yang keluar negeri untuk berobat.Menurutnya,meski mutu pengobatan sebenarnya tidak jauh berbeda, namun Indonesia masih lemah dalam mutu pelayanan dan keselamatan pasien. ${ }^{25}$ Persoalan ini yang membuat sanksi disiplin kedokteran menjadi urgen untuk dibentuk, agar dapat memberikan pengawasan dan pembinaan teradap dokter sehingga hak pasien terlindungi dalam pemberian pelayanan kesehatan.

Selain dibutuhkan, tentunya sanksi disiplin kedokteran harus bermanfaat. Manfaat dari sanksi disiplin kedokteran berkaitan dengan persoalan yang melatarbelakangi dibentuknya sanksi ini, yakni pelayanan medis yang kurang baik ditandai dengan banyaknya malpraktik medis yang berdampak pada menurunnya tingkat kepercayaan masyarakat pada dokter. Sanksi disiplin kedokteran diharapkan dapat memulihkan kondisi pelayanan medis menjadi lebih baik.

Dalam perjalanannya, sanksi disiplin kedokteran belum dapat memberikan manfaat seperti yang diharapkan. Walaupun dengan adanya ketentuan sanksi disiplin kedokteran telah banyak dokter yang diadili dan dijatuhi sanksi, namun tidak memberikan efek jera. Pelanggaran disiplin masih terus ada, bahkan semakin hari semakin meningkat. Data dari MKDKI menyebutkan bahwa antara tahun 2006 sampai 2016 (setelah lahirnya UU Praktik Kedokteran) terdapat 362 pengaduan tentang dugaan pelanggran disiplin. Jumlah ini meningkat dari sebelumnya (sebelum sanksi disiplin kedokteran dibentuk) yaitu 306 pengaduan. Selain data dari MKDKI, fakta di masyarakat pun menunjukkan hal serupa. Hampir secara berkala dapat dibaca dalam media cetak maupun dilihat di media elektronik adanya berbagai berita tentang malpraktik medis. Dari fenomena yang terjadi, diartikan bahwa pelayanan medis belum sepenuhnya baik setelah lahirnya sanksi disiplin kedokteran.

Hasil dari analisa di atas ialah ketentuan sanksi disiplin kedokteran benar-benar dibutuhkan, namum belum bermanfaat untuk mengatasi masalah yang melandasi pembentukannya. Dengan demikian, maka dapat dikatakanketentuan sanksi disiplin berdasarkan asas Kedayagunaan dan Kehasilgunaan tidak efektif untuk melindungi hak pasien sesuai yang dicita-citakan.

\section{Efektivitas Ketentuan Sanksi Disiplin Kedokteran Berdasarkan Asas Kejelasan Rumusan}

Fungsi dari asas-asas pembentukan undang-undang salah satunya ialah untuk menjamin agar undang-undang yang dibentuk dapat dipahami dan diterima oleh mayoritas masyarakat yang dituju oleh undang-undang. Vincent Cyril Richard Arthur Charles (V. C. R. A. C) Crabbe seorang Professor hukum asal Ghana (dalam Bayu), mengatakan bahwa

\footnotetext{
${ }^{24}$ Lihat: Bab I., hal. 4.

${ }^{25}$ http://www.viva.co.id/kemenpar/read/207621-berobat-ke-luar-negeri-devisa-raib-rp100-t.
} 
masyarakat yang dituju dengan pembentukan undang-undang sangat bervariasi dengan tingkat pendidikannya. Untuk itu diperlukan undang-undang yang sederhana dengan komposisi bahasa yang tepat dan sesuai sehingga setiap orang akan dengan tepat memahami istilah didalamnya. ${ }^{26}$ Oleh karena itu salah satu asas pembentukan peraturan perundang-undangan yang harus terwujud di dalam sebuah perundang-undangan ialah asas Kejelasan Rumusan.

Menurut penjelasan Pasal 5 Undang-Undang Nomor 12 Tahun 2011, yang dimaksud dengan asas Kejelasan Rumusan adalah bahwa setiap peraturan perundang-undangan harusmemenuhi persyaratan teknis penyusunan peraturan perundang-undangan, sistematika, pilihan kata atau istilah,serta bahasa hukum yang jelas dan mudah dimengertisehingga tidak menimbulkan berbagai macam interpretasidalam pelaksanaannya.

Berdasarkan pengertian diatas, maka ukuran efektivitas ketentuan sanksi disiplin kedokteran berdasarkan asas kejelasan rumusan ialah bahwa kata atau istilah dalam rumusan ketentuan sanksi disiplin kedokteran jelas dan tidak multitafsir sehingga dapat mudah dimengerti.

Sanksi disiplin kedokteran tercantum dalam Pasal 69 ayat (3) Undang-Undang Praktik Kedokteran, yang berbunyi:

"Sanksi disiplin sebagaimana dimaksud pada ayat (2) dapat berupa:

a. Pemberian peringatan tertulis;

b. Rekomendasi pencabutan surat tanda registrasi atau surat izin praktik; dan/atau

c. Kewajiban mengikuti pendidikan atau pelatihan di institusi pendidikan kedokteran atau kedokteran gigi."

Dari teknis penulisannya, rumusan sanksi disiplin kedokteran tersebut telah memenuhi syarat, namun dari penggunaan pilihan kata atau terminologinya perlu dibahas, terutama penggunaan kata yang tidak lazim dipakai di masyarakat.

a. Pemberian peringatan tertulis. Menurut KBBlkata "pemberian" diartikan sebagai "sesuatu yang diberikan", sedangkan "peringatan" adalah "berita yang mengingatkan akan adanya sesuatu". Maka makna dari rumusan sanksi pemberian peringatan tertulis ialah, sesuatu yang diberikan (kepada dokter) sebagai berita (teguran)akan adanya sesuatu (pelanggaran disiplin) dalam bentuk tulisan atau tertulis.

b. Rekomendasi pencabutan surat tanda registrasi atau surat izin praktik.Pengertian "rekomendasi" dalam KBBI ialah "menganjurkan", sedangkan "pencabutan" ialah "perbuatan mencabut, menarik kembali, atau membatalkan "Surat tanda registrasi", merupakan dokumen hukum atau tanda bukti tertulis yang diterbitkan oleh KKI bagi dokter dan dokter spesialis bahwa yang bersangkutan telah mendaftarkan diri dan telah memenuhi persyaratan serta telah diregistrasi pada KKI. Surat izin praktik adalah bukti tertulis yang diberikan dinas kesehatan kabupaten/kota kepada dokter dan dokter gigi yang akan menjalankan praktik kedokteran setelah memenuhi persyaratan. Dari pengertian terminologi yang dipakai dalam rumusan sanksi ini,

\footnotetext{
${ }^{26}$ Bayu Dwi Anggono, op. cit. hal 59.
} 
maka makna dari rumusan sanksi ini adalah menganjurkan (kepada KKI atau dinas kesehatan kabupaten/kota) untuk mencabut, menarik kembali atau membatalkan STR atau SIP dokter yang dijatuhkan sanksi ini.

C. Kewajiban mengikuti pendidikan atau pelatihan di institusi pendidikan kedokteran atau kedokteran gigi. Menurut KBBIpengertian "kewajiban" ialah "sesuatu yang harus dilaksanakan", sedangkan "Institusi pendidikan kedokteran atau kedokteran gigi" ialah lembaga atau badan yang menyelenggarakan pendidikan kedokteran atau kedokteran gigi. Berdasar pada pengertian dari terminologi yang dipakai, maka makna dari rumusan sanksi ini adalah dokter yang dijatuhkan sanksi ini diharuskan untuk mengikuti pendidikan atau pelatihan di lembaga atau badan yang menyelenggarakan pendidikan kedokteran atau kedokteran gigi.

Dilihat dari hasil analisis yang dilakukan dengan mengartikan kata per kata pada rumusan ketentuan sanksi disiplin kedokteran, dapat dikatakan bahwa rumusan ketentuan sanksi disiplin kedokteran sudah jelas, sebab tidak menimbulkan multitafsir. Dengan demikian sanksi disiplin kedokteran dapat dikatakan efektif untuk melindungi hak pasien berdasarkan asas Kejelasan Rumusan.

\section{Mekanisme Pemberian Sanksi Disiplin Kedokteran Terhadap Dokter}

Mekanisme atau tata cara pemberian sanksi disiplin kedokteran terhadap dokter diatur dengan Perkonsil. Perkonsil yang mengatur mekanisme pemberian sanksi ini sendiri telah mengalami perubahan dari waktu ke waktu, setidaknya terdapat 4 (empat) kali perubahan hingga sekarang ini yang berlaku adalah Perkonsil Nomor 50 Tahun 2017 tentang Tata Cara Penanganan Pengaduan Disiplin Dokter dan Dokter Gigi. Substansi yang diubahsesuai dengan perubahan pada Perkonsil ini adalah terkait kewenangan untuk penyampaian sanksi berupaperingatan tertulis kepada teradu. Sebelumnya diatur bahwa penyampaian sanksi berupa peringatan tertulis merupakan kewenangan MKDKI untuk menyampaikan kepada teradu, hal ini kemudian diubah menjadi kewenangan KKI, kewenangan MKDKI hanya sebatas pada pemberian sanksi kemudian keputusan MKDKI yang menyatakan teradu bersalah diserahkan kepada KKI untuk dilaksanakan. Selain itu, hal lain yang mengalami perubahan adalah terkait waktu pelaksanaan sanksi, perkonsil sebelumnya tidak mengatur tegas, pada perkonsil terbaru nomor 50 Tahun 2017 diatur tegas dengan menyebutkan jumlah hari maksimal yakni 7 (hari).

Mekanisme Pemberian sanksi disiplin kedokteran oleh MKDKI yang diatur dalam Perkonsil Nomor 50 Tahun 2017 diawali dengan pengambilan keputusan oleh majelis yang dilakukan dalam sidangmusyawarah seperti yang telah diatur dalam Pasal 77 ayat (2) Perkonsil ini.Dalam pengambilan keputusan, harus didasarkan pada paling sedikit 3 (tiga) alat bukti yang sah sesuai ayat (1) Pasal 79. Setelah diputuskan,Ketuan MKDKI menyerahkankeputusan MKDKI kepada Ketua KKI untuk dilaksanakan. Diatur dalam Perkonsil ini bahwa dalam pelaksanaan putusan MKDKI sebagai berikut:

1. KKI menerbitkan Surat Keputusan dan menyerahkan Salinan Keputusan MKDKI yang menyatakan Teradu tidak bersalah kepada Teradu yang dilakukan paling lama 7 (tujuh) hari setelah KKI menerima salinan Keputusan MKDKI.

2. KKI menerbitkan Surat Keputusan untuk melaksanaan Keputusan MKDKlyang menyatakan Teradu bersalah yang ditandatangani oleh Ketua Konsil Kedokteran atau Ketua Konsil Kedokteran Gigi sesuai disiplin keilmuan Teradu paling lama 7 (tujuh) hari setelah menerima salinan putusan MKDKI. Kemudian, Surat Keputusan KKI beserta 
salinan Keputusan MKDKI disampaikan kepada teradu, Fasyankes, dan seluruh pihakpihak terkait yaitu Dinas Kesehatan Provinsi, Dinas Kesehatan Kabupaten/Kota yang menerbitkan SIP Teradu, institusi pendidikan kedokteran atau kedokteran gigi tempat pelaksanaan sanksi reschooling.Penyampaian Surat Keputusan KKI kepada Teradu disampaikan paling lambat 7 (tujuh) hari sejak diterbitkan Surat Keputusan KKI melalui surat tercatat.

3. Pencabutan STR berakibat seluruh SIP teradu tidak berlaku.

\section{PENUTUP}

\section{KESIMPULAN}

Berdasarkan hasil penelitian dan pembahasan, dapat ditarik kesimpulkan sebagai berikut.

1) Ketentuan sanksi disiplin kedokteran yang tercantum dalam Pasal 69 ayat (3) UndangUndang Nomor 29 Tahun 2004 tentang Praktik Kedokteran yang meliputi: pemberian peringatan tertulis; rekomendasi pencabutan surat tanda registrasi atau surat izin praktik; dan/atauKewajiban mengikuti pendidikan atau pelatihan di institusi pendidikan kedokteran atau kedokteran gigi sudah efektif untuk melindungi hak pasien ditinjau dari asas pembentukan peraturan perundang-undangan. Dikatakan demikian sebab dari hasil analisis ketentuan sanksi disiplin kedokteran berdasarkan keempat asas pembentukan peraturan perundang-undangan, tiga diantaranya sudah efektif untuk melindungi hak pasien. Hal ini sesuai dengan teori efektifitas yang mengatakan makin besar persentasi target yang tercapai, makin tinggi pula tingkat efektifitasnya. Hasil analisis ketentuan sanksi disiplin berdasarkan asas pembentukan peraturan perundang-undangan sebagai beikut:

a. asas Kejelasan Tujuan, sanksi disiplin kedokteran dibentuk dengan tujuan yang jelas yaitu sebagai bentuk pembinaan dan pengawasan terhadap praktik kedokteran di Indonesia;

b. asas Dapat Dilaksanakan, sanksi disiplin kedokteran dikatakan dapat dilaksanakan karena telah diatur dengan jelas dalam Peraturan KKI (Perkonsil) Nomor 32 Tahun 2015 tentang Tata Cara Penanganan Kasus Dugaan Pelanggaran Disiplin Dokter dan Dokter Gigi.

c. asas Kedayagunaan dan Kehasilgunaan, dengan melihat hal yang melatarbelakangi dibentuknya sanksi disiplin kedokteran yang antara lain tingginya angka pelanggaran disiplin, maka sanksi disiplin benar-benar dibutuhkan dan namun belum bermanfaat bagi masyarakat; dan

d. asas Kejelasan Rumusan, rumusan sanksi disiplin kedokteran sudah jelas dan tidak multitafsir sehingga dapat mudah dimengerti.

Meskipun sudah cukup efektif, namun tidak diaturnya tindakan yang mesti diambil jika Keputusan MKDKI tidak dilaksanakan atau pelaksanaannya melebihi batas waktu yang telah ditentukan dapat berdampak pada sulitnya dilakukan pengawasan terhadap proses pelaksanaan Keputusan MKDKI tersebut.

2) Mekanisme pemberian sanksi disiplin kedokteran diatur dalam Peraturan Konsil Kedokteran Nomor 50 Tahun 2017 tentang Tata Cara Penanganan Pengaduan Disiplin Dokter dan Dokter Gigi telah mengalami beberapa kali perubaahan dari perkonsil- 
perkonsil sebelumnya. Perubahan ini membuat mekanisme pemberian sanksi pada Perkonsil Nomor 50 Tahun 2017 berbeda dengan perkonsil sebelumnya, jika pada perkonsil sebelumnya kewenangan penyampaian sanksi peringatan tertulis merupakan wewenang MKDKI, pada perkonsil ini hal itu merupakan wewenang KKI. Perbedaan lain terlihat pada pembatasan waktu penyampaian petikan keputusan MKDKI kepada KKI dan pembatasan waktu penetapan keputusan KKI tentang pelaksanaan keputusan MKDKI, pada perkonsil sebelumnya tidak diatur secara tegas dengan menyebutkan jumlah hari maksimal, sedangkan pada perkonsil Nomor 50 Tahun 2017 diatur tegas pembatasan jumlah hari pelaksanaannya dengan menyebutkan jumlah harinya.

Mekanisme pemberian sanksi yang diatur pada perkonsil Nomor 50 Tahun 2017 adalah sebagai berikut:

a. MKDKI menetapkan Keputusan MKDKI melalui sidang musyawarah.

b. Ketua MKDKI menerbitkan Keputusan MKDKI dan menyerahkan kepada Ketua KKI.

c. KKI menerbitkan Surat Keputusan untuk melaksanakan Keputusan MKDKI yang menyatakan teradu bersalah yang ditanda tangani oleh Ketua Konsil Kedokteran atau Ketua Konsil Kedokteran Gigi, kemudian Surat Keputusan KKI beserta salinan Keputusan MKDKI disampaikan kepada teradu, Fasyankes, dan seluruh pihak-pihak terkait yaitu Dinas Kesehatan Provinsi, Dinas Kesehatan Kabupaten/Kota yang menerbitkan SIP Teradu, institusi pendidikan kedokteran atau kedokteran gigi tempat pelaksanaan sanksi reschooling.

SARAN

Berdasarkan kesimpulan yang telah diambil dalam penelitian ini, maka dapat dirumuskan saran sebagai berikut:

1) bagi KKI, untuk tercapainya penegakan disiplin dokter yang optimal guna perlindungan terhadap hak pasien, maka perlu adanya pengaturan terkait tindakan yang semestinya diambil ketika Keputusan MKDKI tidak dilaksanakan atau waktu pelaksanaannya melebihi ketentuan pada Perkonsil, agar proses pelaksanaan Keputusan MKDKI dapat mudah diawasi.

2) bagi Dinas Kesehatan Kabupaten/Kota, setelah menerima surat keputusan KKI agar sesegera mungkin untuk melaksanakan keputusan KKI terkait pencabutan SIP sebagai konsekuensi dari pencabutan STR supaya dapat memberikan efek jera demi terlaksananya upaya perlindungan hak pasien. 


\section{DAFTAR PUSTAKA}

Adi, Rianto, 2004, Metodologi Penelitian Sosial dan Hukum, Jakarta: Granit.

Agung, Kurniawan, 2005, Transformasi Pelayanan Publik, Yogyakarta: Pembaruan.

Anggono, Bayu Dwi, 2014, Perkembangan Pembentukan Undang-Undang Di Indonesia, Jakarta: Konpress.

Asshiddiqie, Jimly \& Safa'at, Ali, 2012, Teori Hans Kelsen Tentang Hukum, Jakarta: Konpress.

Atmasasmita, Romli, 2012, Teori Hukum Integratif, Rekonstruksi Terhadap Teori Hkum Pembangunan dan Teori Hukum Progresif, Yogyakarta: Genta Publishing

Effendi, Lutfi, 2003, Pokok-Pokok Hukum Administrasi, Malang: Bayumedia.

Elvandari, Siska, 2005, Hukum Penyelesaiian Sengketa Medis, Yogyakarta: Thafa Media.

Guwandi, J, 2006,Dugaan Mallpraktek Medik \& Draf RPP: Perjanjian Teraupeutik Antara Dokter dan Pasien, Jakarta: FKUI.

-----, 2004, Hukum Medik (Medical Law), Jakarta: FKUI.

Iskandar, 2008, Metodologi Penelitian Pendidikan dan Sosial (Kualitatif dan Kuantitatif), Jakarta: GP Press.

Hamzah, Andi, 2008, Asas-asas Hukum Pidana, Jakarta: Rineka Cipta.

Henrojoyo Soewono, 2005, Perlindungan Hak-hak pasien Dalam Transaksi Terapeutik, Suatu Tinjauan Yuridis Setelah Berlakunya Undang-undang Nomor 29 Tahun 2004 Tentang Praktik Kedokteran, Surabaya: Srikandi.

Kamus Saku Ilmia Populer Edisi Lengkap, Jakarta: Gama Press

Kelsen, Hans, 2015, Teori Umum Tentang Hukum Dan Negara,diterjemahkan oleh Raisul Muttaqien, Bandung: NusaMedia.

Istafandyarie, Anny, 2006,Tanggung Jawab Hukum dan Sanksi bagi Dokter. Buku I, Jakarta: Prestasi Pustaka.

Jayadi,Ahkam, 2005, Memahami Tujuan Penegakan Hukum, Yogyakarta: Rajawali Gedongan Baru.

Lumenta, Benyamin, 1989,Dokter. Citra, Peran, dan Fungsi, Yogyakarta: Kanisius.

Mahmudi, 2005, Manajemen Kinerja Sektor Publik, Yogyakarta: UPP AMP YKPN.

Mertokusumo, Sudikno, 1985, Mengenal Hukum (Suatu Pengatar) Edisi Ketiga, Yogyakarta: Liberti.

------, 1993, Bab-Bab Tentang Penemuan Hukum, Yogyakarta: Citra Aditya Bakti bekerjasama dengan: Konsorsium Ilmu Hukum, Departemen Pendidikan dan Kebudayaan dan The Asia Foundation.

Nasution, Bahder Johan, 2005, Hukum Kesehatan (Pertanggungjawaban Dokter), Jakarta: Rineka Cipta.

Nillas, Risha \& Nufus, Hayatun, 2014, Pedoman Resmi EYD (Ejaan Bahasa Indonesia Yang Disempurnakan), Jakarta: Wahyu Media. 
Notoatmodjo, Soekidjo, 2010, Metodologi Penelitian Kesehatan, Jakarta: Rineka Cipta.

------, 2010, Etika \& Hukum Kesehatan, Jakarta: Rineka Cipta.

Ramelan, Eman, 2015, Perlindungan Hukum Bagi Konsumen Pembeli Satuan Rumah Susun/Strata Title/Apartemen, Yogyakarta: Aswaja Pressindo.

Rahardjo, Satjipto, 2009, Ilmu Hukum, cetakan keenam, Bandung: Citra Aditya Bakti.

Sedarmayanti \& Syarifudin Hidayat,2002, Metodologi Penelitian, Bandung: Mandar Maju.

Soemitro,Ronny Hanitijo, 1988, Metodologi Penelitian Hukum dan Jurimetri, Jakarta: Ghalia Indonesa.

Soekanto, Soerjono, 2014, Faktor-faktor yang Mempengaruhi Penegakan Hukum, Jakarta: Raja Grafido Persada.

------, 2014, Pengantar Penelitan Hukum Cetakan III, Jakarta: Universitas Indonesia.

Solehuddin, 2004,Sistem Sanksi Dalam Hukum Pidana. Jakarta: Raja Grafindo Persada.

Syahrul, Machmud, 2008,Penegakan Hukum dan Perlindungan Hukum bagi Dokter yang Diduga Melakukan Medikal Malpraktek, Jakarta: Mandar Maju.

Tengker, Freddy, 2007, Hak Pasien, Bandung: Mandar Maju.

PERUNDANG-UNDANGAN:

Undang-Undang Dasar Negara Republik Indonesia Tahun 1945.

Kitab Undang-Undang Hukum Pidana.

Kitab Undang-Undang Hukum Perdata.

Undang-Undang Nomor 29 Tahun 2004 Tentang Praktik Kedokteran.

Undang-Undang Nomor 36 Tahun 2009 Tentang Kesehatan.

Undang-Undang Nomor 12 Tahun 2011 Tentang Peraturan Pembentukan PerundangUndangan.

Permenkes RI Nomor 2052/MENKES/PER/X/2011 Tentang

Izin Praktik dan Pelaksanaan Praktik Kedokteran.

Perkonsil RI Nomor 4 Tahun 2011 tentang Disiplin Dokter dan Dokter Gigi

Perkonsil RI Nomor 50 Tahun 2017 tentang Tata Cara Penanganan Pengaduan Disiplin Dokter dan Dokter Gigi

\section{SUMBER DARI INTERNET}

Arif Bambani Amri, "Berobat Ke luar Negeri, Devisa Raib 100 T”, 3 September 2017, http://www.viva.co.id/kemenpar/read/207621-berobat-ke-luar-negeri-devisa-raibrp100-t 
Laporan Sekretariat MKDKI 2011-2016. Tidak dipublikasikan

Internet, Dugaan Pelanggaran Disiplin Terbanyak Akibatnya Kurangnya Komunikasi Dokter dan Pasien, 5 Juni 2016, http://www.depkes.go.id/article/print/1519/dugaanpelanggaran-disiplin-terbanyak-akibat-kurangnya-komunikasi-dokter-dan-pasien.html

Internet, "Putusan Pengadilan TUN Jakarta", 3 September 2017, https://putusan.mahkamahagung.go.id/putusan/downloadpdf/b835fgcb949c2fboa16 $3 a 72 f c 54 c c 9 d b / p d f$

Pulo Lasman Simanjuntak, “Masyarakat Dipersilahkan Mengadu ke MKDKI Bila Ada Dokter Langgar Etika, Dsiplin, dan Pidana”, Internet, 5 Juni 2016, http://www.beritarayaonline.com/2015/05/masyarakat-dipersilahkan-mengaduke.html\#.V1q2ITV97lU

SG Wibisono, "Sampai Akhir 2012, Terjadi 182 Malpraktek", Tempo.co Nasional, 25 maret 2013, internet, 16 juni 2015, http://nasional.tempo.co/read/news/2013.

Tempo.co Nasional “Ketua MKDKI : Kami Tak Mengenal Istilah Malpraktek, 23 desember 2013, internet, 16 juni 2015, http://nasional.tempo.co/read/news/2013.

JURNAL DAN KARYA ILMIAH

Ahmad Reza Pahlevi, "Efektivitas Penerapan Sanksi Mengenai Larangan Parkir Di Bahu Jalan Di Kota Makassar", Skripsi: Fakultas Hukum Universitas Hasanuddin Makassar (tidak diterbitkan), 2010, Hal 41.

Endang Kusumah Astuti, “ Hubungan Hukum Antara Dokter Dan Pasien Dalam Upaya Pelayanan Medis”, 2003, ISSN 0854-6509. 